\title{
Factors Related to Organizational Commitment of Jordanian Auditors: A Structural Model
}

\author{
Muhannad Akram Ahmad \\ Accounting Department, Al Albayt University, Jordan \\ Seif Obeid Al-Shbiel* \\ Accounting Department, Al Albayt University, Jordan
}

\begin{abstract}
The relationships between neuroticism personality and workload and organizational commitment are explored in this study, with job burnout as the potential mediator. The study sample comprised 183 Jordanian auditors and the obtained data prove full mediation of job burnout on the association between workload and organizational commitment, and partial mediation of job burnout on the association between neuroticism personality and organizational commitment. Job burnout and organizational commitment are directly and negatively related. An integrated model grounded by three factors contributing to organizational commitment of auditors is presented in this study.
\end{abstract}

Keywords: Neuroticism; Workload; Organizational commitment; Job burnout; Jordan.

(9) (1) CC BY: Creative Commons Attribution License 4.0

\section{Introduction}

Organizational commitment of employees is influenced by countless of factors, which, many employers have long attempted to comprehend (Muldoon et al., 2017). In the extant literature, Djafri and Noordin (2017), reported organizational commitment as among the most extensively scrutinised variables. In this regard, Kaur (2017), mentioned that most researches on organizational commitment were concentrating on its defining antecedents and consequences. Such extensive interest may be caused by the impact imparted by organizational commitment on attitudes and behaviours such as: turnover, intention to leave, attitudes toward organizational changes, organizational citizenship behaviours (OCBs), and retaining high performance level in organization (Allen and Meyer, 1996;2000; Meyer and Herscovitch, 2001).

Organizational commitment is a concept that has varied definitions. In the work by Mowday et al. (1979), this concept is seen as the comparative strength of the identification and engrossment of a person inside a given organization, whereas in Mowday et al. (1979), and Sanders III et al. (2005), organizational commitment relates to how far the goals and values embraced by employees correspond with the values and norms upheld by the organization. In the context of public accounting companies, the attitudes and behaviours exhibited by audit staff greatly influence the success (or failure) of the company. Appositely, Donnelly et al. (2011), mentioned organizational commitment as a very important attitude of auditors. In fact, as mentioned in several past works (Mathieu and Zajac, 1990; Norris and Niebuhr, 1984; Omar and Ahmad, 2014), commitment decreases absenteeism aside from improving job performance.

Organizational commitment plays a crucial role in an organization, and as mentioned in Martinow et al. (2016), organizational commitment may also become an indicator to the delivered audit quality while also reflecting the reputation of audit profession. Accordingly, lack of commitment may cause turnover to increase and in the context of audit quality, such lack can be a threat. However, it should be noted that low commitment will not necessarily cause auditors to abandon their profession, but having low level of commitment causes these auditors to lack motivation to perform as diligent as they should and this can affect audit quality. Hence, auditors who have low level of commitment but still decide to stay are arguably a bigger threat to the company as opposed to their peers who left the firm or the profession; in fact, the impact of those who left is not readily observable. As organizational commitment impacts the performance of employees, Meyer et al. (2002), suggested that it should be made a priority in the relationship between employee and management.

Furthermore, Savery and Syme (1996), reported that any effort to improve organizational commitment is useful in in reducing of stress levels in the job particularly in staffing and also in the perceived job pressure. In the context of developing countries particularly, reducing the level of stress is crucial (Labatmedienè et al., 2007).

Auditors are continually pressed to produce quality work (Brown and Mendenhall, 1995), and more output within lesser time (Larson, 2011). As a result, auditors are obliged to work long hours as the deadlines are tight, which, leads to high level of work stress. High level of work stress affects the attitude of employees towards their job as well as how they feel towards their organization. Furthermore, how the employees feel about the organization reflects their organizational commitment. On the other hand, job burnout is construed the attitude that individual has towards the job. As reported by Brown and Campbell (1994), and Maslach et al. (2001), both high levels of occupational stress and burnout appear to lead to decreased productivity. In addition, studies have found that job- 
related behaviours including job satisfaction, job performance, learning, motivation, as well as organizational commitment has negative association with high stress and burnout levels (Al Shbail et al., 2018b; Cropanzano et al., 2003; Davey et al., 2001; Demerouti et al., 2002; Llorens et al., 2006).

Also, playing an important role, job burnout also may be reflected in the quality of the conveyed audit as well as in the reputation of the profession (Al Shbail et al., 2018b). As mentioned in past works (Chong and Monroe, 2015; Fogarty et al., 2000; Fogarty and Kalbers, 2006; Sweeney and Summers, 2002). (Almer and Kaplan, 2002; King'ori, 2016), job burnout is a critical factor that impacts the behaviours exhibited by auditors. It is thus possible that auditors experiencing burnout of high levels bring higher threat to audit quality. In this regard, George (2015), expressed the importance of examining the psychological aspects of employees, and relevant to these mentioned aspects, the present study has chosen to focus on job burnout and organizational commitment.

The preliminary studies on burnout were generally anecdotal and descriptive, and as mentioned in Silbiger et al. (2017), many of these works did not present appropriate theoretical contributions or any empirical evidence in lending support to improving the subject. In specific, Smith and Emerson (2017), mentioned workload to be a constant burnout predictor in the context of public accounting. Relevantly, Maslach et al. (2001), reported workout to predict burnout in other professions. Attempts have been made to conceptualize and test the frameworks of burnout within the domain of auditing, and as shown by the extant literature, there exist a number of possible burnout antecedents such as role ambiguity and role conflict (Chong and Monroe, 2015; Low et al., 2001).

Many researchers have extensively discussed the contributing factors of burnout and in this context; the burnout paradigm of Maslach has been the primary focus (Maslach and Leiter, 1997). Here, burnout is regarded as an output of environmental conditions. Somehow, as highlighted in Ghorpade et al. (2011), the paradigm does not provide a comprehensive account for burnout. The authors mentioned the increased attention to the correlation of role of personality with burnout. In the work of Bühler and Land (2003), the authors attempted to comprehend why even within the exact working conditions, not everyone experience burnout. For this reason, including both environment and personality as burnout determinants would seem appropriate in expanding this line of inquiry.

In Swider and Zimmerman (2010), burnout antecedents were discussed. According to Maslach et al. (2001), and Shirom (2003), burnout antecedents fall into three different levels: organisational, occupational, and individual. In addition, Swider and Zimmerman (2010) criticised the biased focus on organisational factors in addition to the exclusion of individual level causes such as personality.

The past works and the presented models assisted in describing the connexion that relates to burnout (Chong and Monroe, 2015; Smith and Emerson, 2017). Accordingly, the present study is unique in a sense that it examines burnout as a possible mediating attribute in workload, neuroticism personality trait with apposite outcome (organizational commitment) within Jordanian public accounting.

Hence, in this study, the question of whether or not burnout can partially or fully mediate such stressorsoutcome relationships is explored. For the purpose, Job-Person fit theory is employed in the present study to determine if auditors that have higher neuroticism personality level will experience high level of job burnout and low organizational commitment level. As such, the present study will attempt to empirically and conceptually contribute in the knowledge of burnout in the context of Jordan.

\section{Theory and Hypotheses}

\subsection{Neuroticism, Burnout and Organizational Commitment}

Gilbert (2013), highlighted a combination of work-factors and personality-factors as predictive antecedents of burnout. As described in Cervone and Winer (2010), personality entails psychological attributes which contribute to the persistent and unique patterns of an individual pertaining to his/her feelings, thoughts and behaviour. Meanwhile, Swider and Zimmerman (2010) highlighted personality as a primary individual-level antecedent of job burnout. Considering that personality is fairly unchanging as opposed to other situational predictors, for instance, workload, it should be treated as the main research focus so that the scope of findings could be expanded.

In this paper, the Big-Five Personality factors are referred. Among the factors (neuroticism, extraversion, agreeableness, conscientiousness and openness to experience), this study has chosen to explore the factor of neuroticism because past studies have indicated this factor being the predictor of countless outcomes that are associated with work including career success and deviance, while also denoting maladaptive and adaptive coping styles (Barrick and Mount, 2000; Colbert et al., 2004; Judge et al., 1999). Hence, Connor-Smith and Flachsbart (2007), suggested the high possibility of these styles to impact the accessibility and usage of coping resources. Relevantly, Schaufeli and Enzmann (1998) highlighted the presence of findings that lend support to the view that possessing coping resources in dealing with work-related demands will decrease the likelihood of individuals in showing strains including burnout (Hobfoll, 2002). Hence, in regards to neuroticism personality and job burnout taking in to account past findings, the hypothesis to be tested in this study is as follows;

H1a: Neuroticism personality will be positively related to job burnout.

The situational antecedents of commitment have been explored in many studies (Meyer et al., 2002; Morrow, 2011). On the other hand, the dispositional antecedents of commitment such as personality traits and locus of control have not been sufficiently explored; which different compared to the case of job burnout. Taking into consideration the strong linkage between job burnout and organisational commitment, such discovery is rather unexpected. More empirical researches on the relationship between personality and organisational commitment should therefore be carried out. Apart from that, there have been insufficient works that look into the linkage between Big Five traits and commitment, while the ones available in the literature are only a few such as Erdheim et al. (2006), and Panaccio and Vandenberghe (2012), and were primarily carried out in developed nations. Hence, the present paper will 
highlight the mechanisms through neuroticism personality as it has been reported to have potential to predispose auditors to experience commitment.

Meanwhile, the knowledge pertaining to the contribution of auditor's personality in organisational commitment development of would provide interesting information for practitioners particularly with respect to auditor selection and recruitment. In actuality, the focus of the extant literature has been on the linkage between personality and behavioural outcomes, including performance such as in Barrick and Mount (1991), Salgado (1997), and Detrick et al. (2004), whereas the impact of personality on job attitudes has not been addressed.

Neuroticism relates to an inclination to demonstrate poor emotional adjustment and feel adverse impact (Judge et al., 2002b). According to Judge et al. (2002a), neurotic person partly intentionally places him/herself into situations that creates negative impact. In addition, Connor-Smith and Flachsbart (2007), reported the linkage between neuroticism and various maladaptive coping mechanisms (e.g., withdrawal, disengagement, and wishful thinking), while Zimmerman et al. (in press) reported the linkage between neuroticism and low job search selfefficacy. Also, neurotic individual has the inclination to mull over the negative side of things (Bono and Judge, 2004), and appears to see neutral events as problematic (Duffy et al., 2006), apart from having the inclination to feel angry and have mood swings (Watson et al., 1994). They are also inclined to exhibit more dysfunctional behaviour (Obeid et al., 2017), feel lower well-being, more stress Ozer and Benet-Martinez (2006), and more burnout (Al Shbail et al., 2018a; Zimmerman et al., 2012). White et al. (2004), further added that neurotic person appears to have poor relationship satisfaction with their partners. Work-wise, such outcomes may cause neurotics to have few productive work experiences (productive work experience contributes to the generation of positive commitment to the organization).

The reviewed literature shows the dearth of studies that explored the linkage between personality and organisational commitment. Erdheim et al. (2006), are among the few that reported the significant linkage between neuroticism personality and continuance commitment. Furthermore, negative relationship was reported between neuroticism and organizational commitment in Raja et al. (2004), Gelade et al. (2006), and Kumar and Bakhshi (2010). In addition, the authors described neuroticism as the primary source of negative affectivity. As such, taking in to account past findings, the hypothesis to be tested in this study is as follows;

H1b: Neuroticism personality will be negatively related to organizational commitment.

\subsection{Workload, Burnout and Organizational Commitment}

In public accounting, the "busy season" is usually during the first calendar quarter. During this time, most audit works are performed, tax returns are to be submitted, and professional services are sought after. During this period, the workload is increased, leading to substantial level of stress. Jones et al. (2010), reported that during the busy season each year, those working in public accounting sector have to deal with the long hours and packed workloads. As reported in Sweeney and Summers (2002), and Jones et al. (2010), in general, the period is marked by elevated stress and possible degradation in performance of auditor.

As shown in past studies, pressures of busy season including auditor burnout can cause audit quality to degrade at the individual auditor level (Sweeney and Summers, 2002). The busy season is crucial in the context of public accounting industry. Still, in the literature, there have been insufficient studies that look into the influence of the substantial workload during this period on critical behavioural variables, attitudes, or outcomes.

Also, among public accountants, burnout is the term that appears commonly during the busy season. In this context, burnout is often used to illustrate the feeling of exhaustion caused by workplace demands. On the other hand, "Job burnout," as explained in Cordes and Dougherty (1993), Maslach (1982), and Sweeney and Summers (2002), is a specified syndrome of psychological stress syndrome in which a pattern of negative responses are the outcomes of work demands or stressors.

Possibly the most frequently cited antecedent to burnout is workload or role overload which was described in Bowling and Kirkendall (2012), as a broad term which encompasses variables that denote the amount or complexity of one's work. Meanwhile, workload was described in Bacharach et al. (1991) as the resultant of having to achieve too many things in a stipulated duration of time. Authors of past studies are all in agreement that too much extended work demands will cause drainage to emotional resources and energy, leading to burnout, job tension, in addition to job dissatisfaction (Cordes and Dougherty, 1993). Lee and Ashforth (1996) and Schaufeli and Enzmann (1998) further added that workload reflects a job demand and often, it is regarded as the main predictor of burnout.

Smith and Emerson (2017), reported the presence of high work overload problem among auditors. Also, some studies including Sweeney and Summers (2002), regard workload as predictor to burnout levels among auditors. In addition, among public accountant, Smith and Emerson (2017), found a significant relationship between burnout and work overload. Therefore, the hypothesis below is presented;

H2a: Workload will be positively related to job burnout.

Higher job stressors experienced by employees cause their organizational commitment to reduce. Fitzgerald et al. (2003), noted that job stressors impact both behaviours and also attitudes of workplace. Accordingly, facing workloads can cause employees to feel astounded by the expectation of successful task completion and this may reduce their positive feelings and attachment toward their organization (Pooja et al., 2016). Meanwhile, Hakanen et al. (2008), found that higher workloads cause work engagement to decrease. In addition, Saks (2006) reported a positive relation between engagement and organizational commitment. In Ahuja et al. (2007), excessive workload appears to result in lower organizational commitment levels amongst employees. Also, work overload and organizational commitment was reported to have significant negative linkage in Jamal (1990), Fisher (2014), and 
Pooja et al. (2016). As can be deduced from past findings, workload should have negative linkage to organizational commitment. The following hypothesis is therefore proposed;

$\boldsymbol{H} \mathbf{2 b}$ : Workload will be negatively related to organizational commitment.

\subsection{Job Burnout and Organizational Commitment}

Organizational psychology is about a comprehension regarding attitudes and behaviours within the environments of work Gilliland and Chan (2001). Meanwhile, being regarded as a vital organizational variable, job burnout has been associated with the deterioration of audit quality Smith and Emerson (2017) and of organizational commitment (Akar, 2018; Hakanen et al., 2008; Li, 2014). As indicated in Leiter (2009), due to its practical significance from the viewpoint of an organization, the connexion that burnout has with organizational commitment has been of particular interest. In past studies (Mathieu and Zajac, 1990; Shore et al., 1995; Whitener and Walz, 1993), correlations between organizational commitment and other variables linked to organization (e.g., turnover intentions, absenteeism, and job performance) have been reported. Hence, as noted by Randall (1987), work attitude therefore is related to organizations, and also significant to the well-being of individual employees.

Chen and $\mathrm{Yu}$ (2014), mentioned the mixed finding regarding the relation between burnout and organizational commitment. For this reason, questions regarding if burnout actually has significant linkage to organizational commitment has emerged (Ashill and Rod, 2011; Hakanen et al., 2008). In addition, the association between burnout and organizational commitment still needs to be explored further. Similarly, more studies need to also be carried out on the relationship between job burnout and organizational commitment in the domain of auditing.

As suggested by past studies (Burke et al., 1984; Chong and Monroe, 2015; Fogarty et al., 2000; Leiter and Maslach, 1988; Maslach, 1982; Salehi and Gholtash, 2011), reduced organisational commitment level is a crucial outcome of job burnout. Such linkage has been reported among police, public accountants, faculty members as well as employees from agencies of government. As reported in , lower organisational commitment seems to be present among internal auditors who feel depersonalised and less accomplished personally. The hypothesis below is therefore presented;

H3: Job burnout will be negatively related to organizational commitment.

\subsection{Job Burnout as a Mediator}

As posited in modern theories such as Mischel and Shoda (1995), Mischel and Shoda (1998), cognitiveaffective personality system (CAPS), the personality of a person impacts the manner in which he or she encodes or assesses the surrounding information. As suggested, the mental encodings of individuals regarding their expectancies and beliefs, affective and physiological response following events, as well as self-regulatory plans, govern the individual's impulsive behavioural inclinations, frustrations, and also fears. Known as cognitive-affective units, these encodings mediate the deliberations on personality-behaviour connexions (Mischel and Ayduk, 2002). It is possible for job burnout to be a set of mental encodings possessed by individuals regarding their reactions and responses towards the constant stress they experience at work. The value added by dispositional- and also processbased investigations to the knowledge regarding the manner in which people cope and react to stress was highlighted by Mischel and Shoda (1998), in detail.

Just like coping, job burnout might be applicable to dispositional- and process-based models in the description of the behaviour of people at work. Hence, this study will attempt to describe how individuals' stable personality traits impact how they respond to situational aspects at work and the behaviours that they show as a response. For instance, it is possible that neurotic individuals will assess and encode a change in their environment (e.g., increased workload) in manners that are distinct as opposed those who have more emotional stability. Neurotic individuals may be inclined to encode change and this causes them to feel emotionally drained and demonstrate aloofness from the job, or these individuals may fail to attain past performance levels which may impact the ensuing outcomes of work.

In addition, in describing the characteristics of stress and outcomes, theories on stress often recognise the importance of person and environment. This can be seen in the research by Riedo et al. (2017), that employs constructs associated with personality traits in studying people experiencing stress. Meanwhile, in other related studies, Rotter (1966), employed locus of control whereas Kobasa (1979), used the construct of hardiness. In past studies, stress has also been associated with workload and under load (French and Caplan, 1972), job demands and decision leverage Karasek and Theorell (1992), and time pressure (Mark and Smith, 2008).

The person and environment make up the bi-factor stress, and in stress studies, and bi-factor stress becomes a facet of the interactive psychological perspective (Lewin, 1951; Magnusson and Endler, 1977; Pervin, 1989). This perspective highlights the joint determination of the individual and the environment regarding the individual's behaviour, attitudes, and well-being. This theory encompasses several dimensions which enable estimation of general individual outcomes such as stress, environmental, and adjustments, which ultimately cause burnout at workplace.

The application of burnout as a mediator of stressors amongst auditors began from the models proposed in Fogarty et al. (2000), Jones et al. (2010), and Smith and Emerson (2017). As mentioned in Smith and Emerson (2017), initial works on role stress were mainly concerned with the direct associations between job-related stressors (e.g., workload) and key outcomes which include organizational commitment and performance. With respect to these works, the outcomes are often contradictory. With respect to these mixed outcomes, Fogarty et al. (2000), related them to misspecification bias caused by the exclusion of primary variables that relate role stressors with job outcomes. 
Relevantly, studies since the last two decades have used the primary mediator variables. Such usage has been to keep refining the stress paradigm among both auditors and accountants, and these include job burnout. For this reason, it is possible for job burnout to be projected by workload and neuroticism and become a mediating connexion between workload, neuroticism personality and organizational commitment. As such, this study proposes the following hypotheses;

H4a: Job burnout mediates the relationship between neuroticism and organizational commitment.

H4b: Job burnout mediates the relationship between workload and organizational commitment.

\section{Research Method \\ 3.1. Participants}

Partakers of this study were auditors from several local and international audit firms in Jordan, and the survey was carried out in Spring 2018. The questionnaires as an instrument of this study were disseminated to these participating auditors. A cover letter was included with the questionnaire. This letter was to inform the partakers of the assurance of confidentiality towards the responses that they provide. The partakers were also assured that they could not be individually identified by the researcher, and that the data would be analysed in summative manner and reported for academic research purposes. The partakers were to return the finished instrument in an enclosed envelope to an administrative staff. The returned questionnaires were then collected by the researchers.

This study reduced the prospective of single-source method bias by having the items comprising the dependent and independent variables separated, while items in each set were combined all through the questionnaire (Podsakoff et al., 2003). In this study, the independent variables are neuroticism personality and workload, whereas the dependent variables are signified by job burnout and organizational commitment. Pilot study was also carried out involving 40 auditors. Following that, minor changes were made to the wording. Then, the formal survey was carried out.

This study disseminated a total of 380 instruments, and obtained 183 usable responses which is equivalent to $48 \%$ response rate. Participants in this study were classed into 2 groups of identical size namely early participants group and late participants group. As revealed from the comparison made to the demographic information and survey responses for the two groups, no statistically significant differences were present. The rate of response seems judicious for survey research. However, the comprehensive demographic information for the pool of prospective respondents was not obtained. For this reason, problems of common method bias need to be addressed (Podsakoff et al., 2012). For the purpose, a full collinearity test (VIF) ${ }^{1}$ was executed. The use of VIF has been proposed in some studies (Al Shbail et al., 2018a; Kock, 2015; Rasoolimanesh et al., 2015). As evidenced by the outcome of analysis, there was no problem of common method bias.

With respect to the respondents participating in this study, 43 of them were audit seniors or "in-charge" auditors, while 37 of them were audit managers. The mean age of the respondents was 29 , while in terms of experience in the profession, the mean attained was five years. Male respondents made up the majority at $82 \%$, and with respect to level of education, the majority (74\%) were bachelor degree's holder, while the remainder (26\%) had master's degree.

\subsection{Measures and Scales}

Organisational Commitment: This construct was measured using an instrument containing 9 items from Mowday et al. (1979). The instrument employs seven-point Likert-type scale (from "1" for strongly disagree to "7" for strongly agree), whereby the scale of 7 denotes organizational commitment of high level. The reliability and validity of for Mowday et al. (1979), nine-item instrument have been reported by past works (Baack et al., 1993; Donnelly et al., 2003; Kwon and Banks, 2004; McManus and Subramaniam, 2014; Sommer et al., 1996; Steers, 1977). Appositely, the Cronbach alpha for this instrument was 0.864 in this study.

Burnout: This construct was measured using the scale-short version of burnout containing 10 items that Malach-Pines (2005), had developed. In this study, the items were presented in Arabic language. This is to ease the measurement of auditors' perceptions for vocational burnout. The items employ 7-point scale for the respondents to indicate their degree of agreement. In this work, the items were tested again for their scale validity and reliability and as shown by the outcomes of the confirmatory factor analysis, the construct of the scale has compatibility with the research data. Here, the scale achieved Cronbach Alpha coefficient of 0.903.

Neuroticism: This construct was measured using 12 items developed by Goldberg (1992), and the items are in semantic differential arrangement, for instance, at ease-nervous, discontented-contented. In responding to the items of this construct, the respondents were provided with 7 options response. Cronbach alpha of 0.871 was attained for this construct.

Workload: This construct was measured using four items obtained from past works (Janssen, 2001; Pooja et al., 2016). The response options for respondents to choose for these items are: "often worked under time pressure" or "often had problems with the pace of work." Cronbach alpha coefficient of 0.887 was attained for this construct scale.

\footnotetext{
${ }^{1}$ As shown by the analysis, there was a minimum collinearity in all predictors' series in the structural model, where the values of VIF are much lower than the threshold value of 3.3, denoting no problem of multicollinearity (Kock, 2015).
} 


\section{Data Analysis}

PLS Path Modeling (PLS-PM) was the method of analysis chosen in this study. The decision to employ PLSPM was underpinned by the following reasons: 1) PLS-PM shows aptness in testing mediation impacts where a feature for completing an indirect effect with various options is available (Al-Shbiel et al., 2018; Obeid et al., 2017). PLS-PM has advanced in a swift manner and therefore with the indices of goodness of fit, it has the capacity to test the theory (Al-Shbiel et al., 2018). The use of PLS-PM allows simultaneous testing of connexions among variables (Ringle et al., 2018). Hence, using PLS-PM, the research hypotheses 1 through 4 are simultaneously tested. Also, consistent estimators (consistent PLS (PLSc)) as proposed by Dijkstra and Henseler (2015), are used to simulate the approach of covariance-based SEM to test or affirm the theory.

It should be noted that the use of PLSc necessitates large sample size (at least 100 cases) (Latan and Ghozali, 2015; Latan et al., 2017; Latan et al., 2018). PLS-PM has been used by past similar works for analysis purposes (AlShbiel, 2016; Al-Shbiel et al., 2018; Al Shbail et al., 2018a;2018b; Obeid et al., 2017). As opposed to other multivariate techniques, PLS-PM has no reliance upon the normality assumption (distribution-free). This is owes to PLS-PM being non-parametric in nature (Latan et al., 2018). Still, for assessment of local model, there should be consideration on assumptions including multicollinearity and goodness of fit indices.

In general, there are four stages of hypothesis data analysis. In the first stage, the measurement model is evaluated. This is to assure the reliability and validity of the construct indicators. During the second stage, the structural model is evaluated. This is to determine the aptness of the model with observational data. Next in the third stage, the direct impacts are tested. This is for ascertaining the relationship between each predictor variable and the obtained result particularly for all direct hypotheses. In the last stage, the indirect impacts on the relationship between neuroticism personality, workload and organizational commitment is tested, with job burnout as mediator.

\subsection{Measurement Model}

Test was carried out on the measurement model. This was to evaluate the constructs' internal consistency reliability, convergent validity and discriminant validity that this study uses. As mentioned in Al-Shbiel et al. (2018), and Hair et al. (2014), internal consistency reliability assesses the degree to which the items function as a measure of the latent constructs. Hair et al. (2017), describe composite reliability as a measure of internal consistency. Furthermore, for each construct, the model of measurement with composite reliability/rho ${ }_{\mathrm{A}}$ greater than the threshold value of 0.7 is regarded as satisfactory (Nunnally and Bernstein, 1994; Richter et al., 2016). As can be seen from the obtained outcomes, the composite reliability for all of the constructs is higher than the cut-off value of 0.70. In specific, neuroticism personality scores 0.894, workload scores 0.896 , job burnout scores 0.905 , and organizational commitment scores 0.895 . All these obtained scores denote the measures' high internal consistency.

Convergent validity is also important to address. As explained in Hair et al. (2017), convergent validity evaluates "the extent to which a measure correlates positively with alternative measures of the same construct" ( $\mathrm{p}$. 112). In order to evaluate convergent validity, the outer loading of the items and the average variance extracted (AVE) are checked. The loading factor, average variance extracted (AVE) as well as reliability value obtained from the measurement model analysis for each variable had loading factor $>0.70$ and AVE $>0.50$, and according to Henseler (2017), obtaining such values means that rule of thumb proposed is satisfied. It should be noted that several questions had a loading factor $<0.70$ but if AVE value $>0.50$ they are tolerable. In Hair et al. (2017), it is suggested that indicators that have weaker factor loadings is retained if other indicators with high loadings can describe $50 \%$ of the variance $(\mathrm{AVE}=0.50)$, at minimum. The internal consistency reliability and convergent validity outcomes are provided in Table 1. 
Table-1. Measurement model

\begin{tabular}{|c|c|c|c|c|c|}
\hline Construct & Items & Loadings & Cronbach's Alpha & rho $_{\mathrm{A}}$ & AVE \\
\hline \multirow{12}{*}{$\begin{array}{l}\text { Neuroticism } \\
\text { personality }\end{array}$} & NP-1 & 0.823 & \multirow[t]{12}{*}{0.871} & \multirow[t]{12}{*}{0.894} & \multirow[t]{12}{*}{0.513} \\
\hline & NP-2 & 0.872 & & & \\
\hline & NP-3 & 0.854 & & & \\
\hline & NP-4 & 0.719 & & & \\
\hline & NP-5 & 0.695 & & & \\
\hline & NP-6 & 0.822 & & & \\
\hline & NP-7 & 0.767 & & & \\
\hline & NP-8 & 0.848 & & & \\
\hline & NP-9 & 0.908 & & & \\
\hline & NP-10 & 0.675 & & & \\
\hline & NP-11 & 0.834 & & & \\
\hline & NP-12 & 0.915 & & & \\
\hline \multirow[t]{4}{*}{ Workload } & WL-1 & 0.886 & \multirow[t]{4}{*}{0.887} & \multirow[t]{4}{*}{0.896} & \multirow[t]{4}{*}{0.747} \\
\hline & WL-2 & 0.932 & & & \\
\hline & WL-3 & 0.843 & & & \\
\hline & WL-4 & 0.911 & & & \\
\hline \multirow[t]{10}{*}{ Job burnout } & JB-1 & 0.877 & \multirow[t]{10}{*}{0.903} & \multirow[t]{10}{*}{0.905} & \multirow[t]{10}{*}{0.556} \\
\hline & JB-2 & 0.692 & & & \\
\hline & JB-3 & 0.902 & & & \\
\hline & JB-4 & 0.773 & & & \\
\hline & JB-5 & 0.851 & & & \\
\hline & JB-6 & 0.897 & & & \\
\hline & JB-7 & 0.921 & & & \\
\hline & JB-8 & 0.748 & & & \\
\hline & JB-9 & 0.791 & & & \\
\hline & JB-10 & 0.826 & & & \\
\hline \multirow{9}{*}{$\begin{array}{l}\text { Organizational } \\
\text { commitment }\end{array}$} & OC-1 & 0.889 & \multirow[t]{9}{*}{0.864} & \multirow[t]{9}{*}{0.895} & \multirow[t]{9}{*}{0.617} \\
\hline & OC-2 & 0.941 & & & \\
\hline & $\mathrm{OC}-3$ & 0.842 & & & \\
\hline & OC-4 & 0.795 & & & \\
\hline & OC-5 & 0.881 & & & \\
\hline & OC-6 & 0.904 & & & \\
\hline & OC-7 & 0.855 & & & \\
\hline & OC-8 & 0.762 & & & \\
\hline & OC-9 & 0.836 & & & \\
\hline
\end{tabular}

The discriminant validity of the reflective constructs is determined using two criteria namely the FornellLarcker criterion and the heterotrait-monotrait (HTMT) ratio (Henseler et al., 2015; Voorhees et al., 2016). Accordingly, Table 2 shows that the square root of the AVE on diagonal lines is higher than the correlation between the constructs in the model. What can be implied from the presented values is that all variables in this research model satisfy the requirement of the discriminant validity. Using HTMT in the discriminant validity testing, the value obtained is less than 0.85 , denoting the adherence to the rule of thumb recommended (Al-Shbiel et al., 2018; Henseler et al., 2017).

Table-2. Discriminant validity

\begin{tabular}{l|l|l|l|l}
\hline Fornell-Larcker criterion \\
\hline Construct & $\mathbf{1}$ & $\mathbf{2}$ & $\mathbf{3}$ & $\mathbf{4}$ \\
\hline NP & 0.795 & & & \\
\hline JB & 0.643 & 0.733 & & \\
\hline WL & 0.558 & 0.578 & 0.865 & \\
\hline OC & 0.560 & 0.712 & 0.435 & 0.719 \\
\hline HTMT criterion & & & & \\
\hline NP & 0.835 & & & \\
\hline JB & 0.630 & 0.642 & & \\
\hline WL & 0.622 & 0.787 & 0.485 & \\
\hline OC &
\end{tabular}

Note: $\mathrm{NP}=$ Neuroticism personality,

$\mathrm{JB}=\mathrm{Job}$ burnout, $\mathrm{OC}=$ Organizational commitment 


\subsection{Structural Model}

The model fit needs to be tested using the standardized root mean square residual (SRMR) as the root mean square discrepancy between the perceived correlations and the model-implied correlations (Hu and Bentler, 1998). as well as other fit indices (i.e., normed fit index (NFI)) for testing the research's model fit (Henseler et al., 2014). This model fit test is done prior to having the model tested. The test yielded SRMR of $0.063<0.080$ and the normed fix index (NFI) $0.913>0.80$. What can be construed from these outcomes is that the model proposed in this work fits the empirical data (Al-Shbiel et al., 2018; Hu and Bentler, 1999). Problems of collinearity need to be examined as well. For the purpose, the values of VIF of all predictor constructs are examined. From the obtained outcomes, all values of VIF values are smaller than the established threshold of 3.3 (Kock, 2015). As mentioned in Kock (2015), the model can be regarded as having no common method bias if all VIFs obtained from a full collinearity test are equivalent to or less than 3.3. As such, among the constructs within the structural model, it appears that collinearity is not a serious problem. Hence, the results can be examined further.

The structural model was further assessed by scrutinizing the determination coefficient $\left(\mathrm{R}^{2}\right.$ or adjusted $\left.\mathrm{R}^{2}\right), f 2$ and $\mathrm{Q}^{2}$ which measures the model's predictive power. Determination coefficient denotes the amount of variance in the endogenous variable which is describable using all exogenous variables. Accordingly, in some disciplines, the value of higher than 0.20 for determination coefficient is deemed as high, whereas good values of determination coefficient should fall between 0.25 and 0.50 .

Meanwhile, standard errors and t-statistics are produced using the technique of bootstrapping. Standard errors and t-statistics ease the assessment of statistical significance of the path coefficients. The outcomes obtained denote the significance of the conjectured relationships with the exclusion of hypothesis $2 \mathrm{~b}$. The use of percentile bootstrapping also led to similar results at $95 \%$ confidence interval (Henseler et al., 2016; Henseler et al., 2017). An interval without zero denotes the structural path coefficient being significantly different from zero, at a confidence level of $95 \%$ (Castro and Roldán, 2015). As such, the path coefficient can be deemed to be significant.

Table-3. Structural model results

\begin{tabular}{l|l|l|l|l|l|l}
\hline Constructs & $\mathbf{A d j}^{\mathbf{2}} \mathbf{f}^{\mathbf{2}}$ & $\mathbf{Q}^{\mathbf{2}}$ & VIF & SRMR & NFI \\
\hline Neuroticism Personality & - & $0.261-0.026$ & - & 2.828 & - & - \\
\hline Workload & - & $0.198-0.091$ & - & 1.564 & - & - \\
\hline Job Burnout & 0.792 & 0.637 & 0.325 & 2.217 & 0.063 & 0.913 \\
\hline $\begin{array}{l}\text { Organizational } \\
\text { Commitment }\end{array}$ & 0.646 & - & 0.232 & - & 0.063 & 0.913 \\
\hline
\end{tabular}

Table-4. Hypotheses verification (direct relationship)

\begin{tabular}{|c|c|c|c|c|c|}
\hline \multirow[t]{2}{*}{ Structural path } & \multirow[t]{2}{*}{$\begin{array}{l}\text { Path coefficient } \\
\text { and (T-Statistics) }\end{array}$} & \multicolumn{2}{|c|}{$\begin{array}{l}\text { Percentile } 95 \% \\
\text { confidence intervals }\end{array}$} & \multirow[t]{2}{*}{$\begin{array}{l}\text { P- } \\
\text { Values }\end{array}$} & \multirow[t]{2}{*}{ Conclusion } \\
\hline & & $95 \% \mathrm{LL}$ & $95 \% \mathrm{UL}$ & & \\
\hline H1a: NP->JB & $0.791(12.671)$ & \multicolumn{2}{|c|}{$(0.685 ; 0.921)$ Sig } & 0.000 & Supported \\
\hline H1b: NP->OC & $-0.233(1.968)$ & \multicolumn{2}{|c|}{$(-0.175 ;-0.044)$ Sig } & 0.004 & Supported \\
\hline H2a: WL->JB & $0.248(2.362)$ & \multicolumn{2}{|c|}{$(0.136 ; 0.520)$ Sig } & 0.001 & Supported \\
\hline H2b: WL->OC & $0.009(0.253)$ & \multirow{2}{*}{\multicolumn{2}{|c|}{$(-0.013 ; 0.220)$ Insig }} & 0.963 & Not supported \\
\hline H3: JB->OC & $-0.433(4.626)$ & & & 0.000 & Supported \\
\hline
\end{tabular}

Note: $\mathrm{NP}=$ Neuroticism personality, WL $=$ Workload, JB = Job burnout, OC= Organizational commitment.

The obtained results are the complete affirmation of this study's projection on the effect of neuroticism personality as a predictor of job burnout and organizational commitment. As shown in Table 4, the standardized path coefficients demonstrate that neuroticism has a significant positive connexion with job burnout and a significant negative linkage with organizational commitment where: $\beta=0.791,-0.233$, p-value $<0.05$ respectively. Furthermore, the results from the method of bootstrap also have no absolute zero value, which means affirmation to H1a and H1b. In addition, workload has a significant positive linkage to job burnout $(\mathrm{H} 2 \mathrm{a}, \beta=0.248, \mathrm{p}<0.05)$ and no relation with organizational commitment, which means support to H2a. This study also provides affirmation of the effect of job burnout, where it is found to have significant and adverse relation (-0.433) to organizational commitment (p-value of $<0.05)$. Furthermore, bootstrapping confidence intervals yields outcomes of -0.645 and -0.367 , which means support to Hypothesis 3 .

In the assessment of the model, evaluation of the impact of job burnout as a mediator between neuroticism personality, workload and organizational commitment is the final step. Here, the indirect effect is computed (ab) and for the purpose, the work of Cepeda et al. (2018), was referred. Accordingly, computation was made to the percentile bootstrap and bias corrected bootstrap. Effect of mediation also determined through the assessment of the significance of the indirect effect. The confidence intervals (Panaccio and Vandenberghe) were used in significance valuation. Here, in order to be significant, the value of 0 must not be present; Table 5 can be referred. The outcomes in the present study show significant indirect effect. This is an affirmation of job burnout acting as mediator between neuroticism, workload and organizational commitment, which denotes support to H4a and H4b.

Following the determination of indirect effect, the significance of the direct effect (c') is examined. This is to determine if the mediation is full or partial. Hence, evaluation is done on the direct effect's significance with no inclusion of the mediating variable between neuroticism, workload and organizational commitment. Table 4 presents 
the details. Furthermore, considering the insignificance of the direct effect of workload on organizational commitment and the significance of indirect effect through job burnout, there is full mediation relationship.

In addition, there appears significant direct and indirect impact of neuroticism on organizational commitment, and a partial mediation relationship is developed. As affirmation to the result, the Variance Accounted for (VAF) is computed. VAF determines the size of the indirect effect on the total effect. Here, according to Hair et al. (2016), if the VAF obtained is less than $20 \%$, then it means almost zero mediation. Meanwhile, VAF higher than $20 \%$ and lower than $80 \%$ denotes a classic partial mediation whereas VAF higher than $80 \%$ denotes full mediation. Table 5 highlights the details.

Table-5. Mediating effects test

\begin{tabular}{|c|c|c|c|c|c|c|c|}
\hline \multirow[t]{2}{*}{ Hypothesis } & \multirow{2}{*}{$\begin{array}{l}\text { Path } \\
\text { coeff. } \\
\text { (a) }\end{array}$} & \multirow{2}{*}{$\begin{array}{l}\text { Path } \\
\text { coeff. (b) }\end{array}$} & \multirow{2}{*}{$\begin{array}{l}\text { Path } \\
\text { coeff. } \\
(\mathbf{a} * \mathbf{b})\end{array}$} & \multicolumn{2}{|c|}{ Percentile 95\% CI } & \multirow[t]{2}{*}{$\mathbf{V A F}^{\mathbf{a}}$} & \multirow[t]{2}{*}{ Conclusion } \\
\hline & & & & $95 \% \mathrm{LL}$ & $95 \% \mathrm{UL}$ & & \\
\hline NP->JB->OC & 0.791 & -0.433 & -0.343 & \multicolumn{2}{|c|}{$(-0.923 ;-0.539)$} & $64.8 \%$ & Partial mediation \\
\hline WL->JB->OC & 0.248 & -0.433 & -0.107 & \multicolumn{2}{|c|}{$(-0.359 ;-0.126)$} & $90.6 \%$ & Full mediation \\
\hline
\end{tabular}

Note: ${ }^{*} \mathrm{p}<0.05,{ }^{\mathrm{a}} \mathrm{VAF}=$ Variance accounted for, $\mathrm{NP}=$ Neuroticism personality, WL $=$ Workload, JB = Job burnout, OC $=$ Organizational commitment.

\section{Conclusion, Discussion and Recommendations}

Workload and neuroticism personality appear to be crucial burnout antecedents and these consequently foretell auditors' organizational commitment. In detail, workload and neuroticism personality are positively correlated with job burnout. However, with organizational commitment, only the neuroticism personality shows significant direct correlation. Job burnout shows a significant positive correlation with organizational commitment. Job burnout is also found to fully mediate the linkage between workload and organizational commitment. On the other hand, with respect to the relationship between neuroticism and organizational commitment, job burnout appears to partially mediate. These findings are affirmation and expansion of linkage that past works have established between burnout antecedents and its outcomes.

Appositely, several limitations have been identified in this study, and these limitations could be addressed in forthcoming works. To begin with, the data obtained in this work are cross-sectional data and therefore, deduction on the causal direction of relationships cannot be drawn. It is in fact worthy to perform longitudinal studies within the duration of several months or years even, as this will allow the examination of cross-lagged relationships. The second limitation of this study is its dependency towards self-reported information particularly pertaining to traits, burnout, and organizational commitment, which causes the possible occurrence of common method bias. However, in this study, several statistical steps were taken in order to lessen common method bias. Still, longitudinal designs and multi-source data are of value as they can comprehensively rule out its effects.

Additionally, burnout appears to be the primary outcome for consideration (mediator variable). Furthermore, considering that engagement has linkage with (even though not opposite of) job burnout (Hakanen et al., 2006), the contribution of neuroticism personality to (lower) engagement level might also be beneficial.

Apart from the above suggestions, future works should consider different personal traits as predictor variables of burnout. This will enrich the understanding regarding the interrelatedness between personal resources for burnout (and engagement). Also, this study is proving the value of auditor burnout as a construct which could further be employed in other domains as well. In this regard, other possible predictors could be scrutinized. Notably, only two factors linked to burnout were used in this work and for this reason, future studies could consider including more predictors of job burnout for instance leadership behaviours.

\section{References}

Ahuja, M. K., Chudoba, K. M., Kacmar, C. J., McKnight, D. H. and George, J. F. (2007). IT road warriors: Balancing work-family conflict, job autonomy, and work overload to mitigate turnover intentions. MIS Quarterly, 31(1): 1-17. Available: https://doi.org/10.2307/25148778

Akar, H. (2018). The relationships between quality of work life, school alienation, burnout, affective commitment and organizational citizenship: A study on teachers. European Journal of Educational Research, 7(2): 16980. Available: https://eric.ed.gov/?id=EJ1175342

Al-Shbiel, S. O. (2016). An examination the factors influence on unethical behaviour among Jordanian external auditors: Job satisfaction as a mediator. International Journal of Academic Research in Accounting, Finance and Management Sciences, 6(3): 285-96. Available: https://doi.org/10.6007/IJARAFMS/v6$\underline{\mathrm{i} 3 / 2276}$

Al-Shbiel, S. O., Ahmad, M. A., Al-Shbail, A. M., Al-Mawali, H. and Al-Shbail, M. O. (2018). The mediating role of work engagement in the relationship between organizational justice and junior accountants' turnover intentions. Academy of Accounting \& Financial Studies Journal, 22(1): 1-23.

Al Shbail, M., Salleh, Z. and Mohd Nor, M. (2018a). Antecedents of burnout and its relationship to internal audit quality. Business and Economic Horizons, 14(4): 789-817. Available: http://dx.doi.org/10.15208/beh.2018.55

Al Shbail, M., Salleh, Z. and Mohd Nor, M. (2018b). The effect of ethical tension and time pressure on job burnout and premature sign-off. Journal of Business and Retail Management Research, 12(4): 43-53. Available: https://doi.org/10.24052/JBRMR/V12IS04/ART-05 
Allen, N. J. and Meyer, J. P. (1996). Affective, continuance, and normative commitment to the organization: An examination of construct validity. Journal of Vocational Behavior, 49(3): 252-76. Available: https://doi.org/10.1006/jvbe.1996.0043

Allen, N. J. and Meyer, J. P. (2000). Construct validation in organizational behavior research: The case of organizational commitment. In R. D. Goffin \& E. Helmes (Eds.), Problems and solutions in human assessment: Honouring Douglas N. Jackson at seventy. MA: Kluwer: Norwell. 285-314.

Almer, E. and Kaplan, S. (2002). The effects of flexible work arrangements on stressors, burnout, and behavioral job outcomes in public accounting. Behavioral Research in Accounting, 14(1): 1-34. Available: https://doi.org/10.2308/bria.2002.14.1.1

Ashill, N. J. and Rod, M. (2011). Burnout processes in non-clinical health service encounters. Journal of Business Research, 64(10): 1116-27. Available: https://doi.org/10.1016/j.jbusres.2010.11.004

Baack, D., Luthans, F. and Rogers, J. (1993). Analysis of the organizational commitment of clergy members. Journal of Managerial Issues, 5(2): 232-53. Available: https://www.jstor.org/stable/40603980

Bacharach, S. B., Bamberger, P. and Conley, S. (1991). Work-home conflict among nurses and engineers: Mediating the impact of role stress on burnout and satisfaction at work. Journal of Organizational Behavior, 12(1): 39-53. Available: https://doi.org/10.1002/job.4030120104

Barrick, M. R. and Mount, M. K. (1991). The big five personality dimensions and job performance: a meta-analysis. Personnel Psychology, 44(1): 1-26. Available: https://doi.org/10.1111/j.1744-6570.1991.tb00688.x

Barrick, M. R. and Mount, M. K. (2000). Select on Conscientiousness and Emotional Stability. In E. A. Locke (Ed.), Handbook of principles of organizational behavior. Oxford, England: Blackwell. 15-28.

Bono, J. E. and Judge, T. A. (2004). Personality and transformational and transactional leadership: a meta-analysis. Journal of Applied Psychology, 89(5): 901-10. Available: http://dx.doi.org/10.1037/0021-9010.89.5.901

Bowling, N. A. and Kirkendall, C. (2012). Workload: A review of causes, consequences, and potential interventions. In J. Houdmont, S. Leka, \& R. R. Sinclair (Eds.), Contemporary occupational health psychology: Global perspectives on research and practice. 2 vols.: Wiley-Blackwell: Chichester, UK. 221-38.

Brown and Campbell, E. A. (1994). Stress and policing: Sources and strategies. John Wiley \& Sons: New York.

Brown and Mendenhall, S. (1995). Stress and components of the internal auditor's job. Internal Audit, 10: 31-31.

Bühler, K. E. and Land, T. (2003). Burnout and personality in intensive care: an empirical study. Hospital Topics, 81(4): 5-12. Available: https://doi.org/10.1080/00185860309598028

Burke, R. J., Shearer, J. and Deszca, G. (1984). Burnout among men and women in police work: An examination of the Cherniss model. Journal of Health and Human Resources Administration, 7(2): 162-88. Available: https://www.jstor.org/stable/25780191

Castro, I. and Roldán, J. L. (2015). Alliance portfolio management: dimensions and performance. European Management Review, 12(2): 63-81. Available: https://doi.org/10.1111/emre.12042

Cepeda, G., Nitzl, C. and Roldán, J. L. (2018). Mediation analyses in partial least squares structural equation modeling: Guidelines and empirical examples. H. Latan, H., \& R. Noonan (Eds.), Partial least squares path modeling: Basic concepts, methodological issues and applications. Springer: New York.

Cervone, D. and Winer, E. (2010). On social-cognitive and dialogical models of personality: Theoretical and empirical steps toward an integrative view. International Journal for Dialogical Science, 4(1): 5-22. Available: http://www.nuigalway.ie/business-public-policylaw/cairnes/ourstaff/accountingstaff/bredasweeney/

Chen, C. F. and Yu, T. (2014). Effects of positive vs negative forces on the burnout-commitment-turnover relationship. Journal of Service Management, 25(3): 388-410. Available: https://doi.org/10.1108/JOSM-012012-0003

Chong, V. K. and Monroe, G. S. (2015). The impact of the antecedents and consequences of job burnout on junior accountants' turnover intentions: a structural equation modelling approach. Accounting \& Finance, 55(1): 105-32. Available: https://doi.org/10.1111/acfi.12049

Colbert, A. E., Mount, M. K., Harter, J. K., Witt, L. A. and Barrick, M. R. (2004). Interactive effects of personality and perceptions of the work situation on workplace deviance. Journal of Applied Psychology, 89(4): 599609. Available: http://dx.doi.org/10.1037/0021-9010.89.4.5999

Connor-Smith, J. K. and Flachsbart, C. (2007). Relations between personality and coping: a meta-analysis. Journal of Personality And Social Psychology, 93(6): 1080-107. Available: http://dx.doi.org/10.1037/00223514.93.6.1080

Cordes, C. L. and Dougherty, T. W. (1993). A review and an integration of research on job burnout. Academy of management Review, 18(4): 621-56. Available: https://doi.org/10.5465/amr.1993.9402210153

Cropanzano, R., Rupp, D. E. and Byrne, Z. S. (2003). The relationship of emotional exhaustion to work attitudes, job performance, and organizational citizenship behaviors. Journal of Applied Psychology, 88(1): 160-69. Available: http://dx.doi.org/10.1037/0021-9010.88.1.160

Davey, J. D., Obst, P. L. and Sheehan, M. C. (2001). Demographic and workplace characteristics which add to the prediction of stress and job satisfaction within the police workplace. Journal of Police and Criminal Psychology, 16(1): 29-39. Available: https://doi.org/10.1007/BF02802731

Demerouti, E., Bakker, A., Nachreiner, F. and Ebbinghaus, M. (2002). From mental strain to burnout. European Journal of Work and Organizational Psychology, 11(4): 423-41. Available: https://doi.org/10.1080/13594320244000274 
Detrick, P., Chibnall, J. T. and Luebbert, M. C. (2004). The revised NEO personality inventory as predictor of police academy performance. Criminal Justice and Behavior, 31(6): 676-94. Available: https://doi.org/10.1177/0093854804268751

Dijkstra, T. K. and Henseler, J. (2015). Consistent partial least squares path modeling. MIS Quarterly, 39(2): 297316.

Djafri, F. and Noordin, K. (2017). The impact of workplace spirituality on organizational commitment: A case study of Takaful agents in Malaysia. 33(3): 384-96. Available: https://doi.org/10.1108/H-02-2017-0018

Donnelly, D. P., Quirin, J. J. and O'Bryan, D. (2003). Auditor acceptance of dysfunctional audit behavior: An explanatory model using auditors' personal characteristics. Behavioral Research in Accounting, 15(1): 87110. Available: https://doi.org/10.2308/bria.2003.15.1.87

Donnelly, D. P., Quirin, J. J. and O'Bryan, D. (2011). Attitudes toward dysfunctional audit behavior: The effects of locus of control, organizational commitment, and position. Journal of Applied Business Research, 19(1): 85-108. Available: https://doi.org/10.19030/jabr.v19i1.2151

Duffy, M. K., Shaw, J. D., Scott, K. L. and Tepper, B. J. (2006). The moderating roles of self-esteem and neuroticism in the relationship between group and individual undermining behavior. Journal of Applied Psychology, 91(5): 1066-77. Available: http://dx.doi.org/10.1037/0021-9010.91.5.1066

Erdheim, J., Wang, M. and Zickar, M. J. (2006). Linking the Big Five personality constructs to organizational commitment. Personality and Individual Differences, 41(5): 959-70. Available: https://doi.org/10.1016/j.paid.2006.04.005

Fisher, D. M. (2014). A multilevel cross-cultural examination of role overload and organizational commitment: Investigating the interactive effects of context. Journal of Applied Psychology, 99(4): 723-36. Available: http://dx.doi.org/10.1037/a0035861

Fitzgerald, S. T., Haythornthwaite, J. A., Suchday, S. and Ewart, C. K. (2003). Anger in young black and white workers: Effects of job control, dissatisfaction, and support. Journal of Behavioral Medicine, 26(4): 283-96. Available: https://doi.org/10.1023/A:1024228026022

Fogarty, T. J. and Kalbers, L. P. (2006). Internal auditor burnout: An examination of behavioral consequences. Advances in Accounting Behavioral Research, 9: 51-86. Available: https://www.emeraldinsight.com/doi/abs/10.1016/S1475-1488(06)09003-X

Fogarty, T. J., Singh, J., Rhoads, G. K. and Moore, R. K. (2000). Antecedents and consequences of burnout in accounting: Beyond the role stress model. Behavioral Research in Accounting, 12: 31-67. Available: http://ssrn.com/abstract $=37387$

French, J. R. and Caplan, R. D. (1972). Organizational stress and individual strain. In A. J. Marrow (Ed.), The failure of success. AMACON: New York. 30-66.

Gelade, G. A., Dobson, P. and Gilbert, P. (2006). National differences in organizational commitment: Effect of economy, product of personality, or consequence of culture. Journal of Cross-Cultural Psychology, 37(5): 542-56. Available: https://doi.org/10.1177/0022022106290477

George, E. (2015). Job related stress and job satisfaction: a comparative study among bank employees. Journal of Management Development, 34(3): 316-29. Available: https://doi.org/10.1108/JMD-07-2013-0097

Ghorpade, J., Lackritz, J. and Singh, G. (2011). Personality as a moderator of the relationship between role conflict, role ambiguity, and burnout. Journal of Applied Social Psychology, 41(6): 1275-98. Available: https://doi.org/10.1111/j.1559-1816.2011.00763.x

Gilbert, G. (2013). The relationship between personality, areas of work and burnout among social care workers in Ireland. Higher Diploma thesis, Dublin Business School, Ireland. https://esource.dbs.ie/bitstream/handle/10788/1603/hdip_gilbert_g_2013.pdf?sequence\%253D1

Gilliland, S. and Chan, D. (2001). Justice in organizations: Theory, methods, and applications. In: Anderson N, Ones DS, Sinangil HK, et al. (eds) Handbook of industrial, work, and organizational psychology: Organizational psychology. Sage: Thousand Oaks, CA. 143-65.

Goldberg, L. R. (1992). The development of markers for the Big-Five factor structure. Psychological Assessment, 4(1): 26-42. Available: http://dx.doi.org/10.1037/1040-3590.4.1.26

Hair, Sarstedt, M., Hopkins, L. and Kuppelwieser, V. G. (2014). Partial least squares structural equation modeling (PLS-SEM): An emerging tool in business research. European Business Review, 26(2): 106-21. Available: https://doi.org/10.1108/EBR-10-2013-0128

Hair, Hult, M., Ringle, C. and Sarstedt, M. (2016). A primer on partial least squares structural equation modeling (PLS-SEM). Sage Publications.

Hair, Hult, G., Ringle, C. and Sarstedt, M. (2017). A primer on partial least squares structural equation modeling (PLS-SEM). 2nd ed edn: Sage: Thousand Oaks, CA.

Hakanen, Bakker, A. B. and Schaufeli, W. B. (2006). Burnout and work engagement among teachers. Journal of School Psychology, 43(6): 495-513. Available: https://doi.org/10.1016/j.jsp.2005.11.001

Hakanen, Schaufeli, W. and Ahola, K. (2008). A three-year cross-lagged panel study on the Job Demands-Resources model: Do home demands and resources play a role. Work \& Stress, 22(3): 224-41. Available: https://doi.org/10.1080/02678370802379432

Henseler (2017). Bridging design and behavioral research with variance-based structural equation modeling. Journal of Advertising, 46(1): 178-92. Available: https://doi.org/10.1080/00913367.2017.1281780 
Henseler, Ringle, C. and Sarstedt, M. (2015). A new criterion for assessing discriminant validity in variance-based structural equation modeling. Journal of the Academy of Marketing Science, 43(1): 115-35. Available: https://doi.org/10.1007/s11747-014-0403-8

Henseler, Hubona, G. and Ray, P. (2016). Using PLS path modeling in new technology research: updated guidelines. Industrial Management \& Data Systems, 116(1): 2-20. Available: https://doi.org/10.1108/IMDS-09-2015$\underline{0382}$

Henseler, Hubona, G. and Ray, P. A. (2017). Partial least squares path modeling: updated guidelines. In: Latan, H., Noonan, R. (Eds.), Partial Least Squares Path Modeling: Basic Concepts, Methodological Issues and Applications. Springer International Publishing: Cham. 19-39.

Henseler, Dijkstra, T. K., Sarstedt, M., Ringle, C. M., Diamantopoulos, A., Straub, D. W. and Calantone, R. J. (2014). Common beliefs and reality about PLS: Comments on Rönkkö and Evermann (2013). Organizational Research Methods, 17(2): 182-209. Available: https://doi.org/10.1177/1094428114526928

Hobfoll, S. E. (2002). Social and psychological resources and adaptation. Review of General Psychology, 6(4): 30724. Available: https://doi.org/10.1037/1089-2680.6.4.307

Hu, L. t. and Bentler, P. M. (1998). Fit indices in covariance structure modeling: Sensitivity to underparameterized model misspecification. Psychological Methods, 3(4): 424-53. Available: http://dx.doi.org/10.1037/1082989X.3.4.424

Hu, L. T. and Bentler, P. M. (1999). Cutoff criteria for fit indexes in covariance structure analysis: Conventional criteria versus new alternatives. Structural equation modeling: a multidisciplinary journal, 6(1): 1-55. Available: https://doi.org/10.1080/10705519909540118

Jamal, M. (1990). Relationship of job stress and Type-A behavior to employees' job satisfaction, organizational commitment, psychosomatic health problems, and turnover motivation. Human Relations, 43(8): 727-38. Available: https://doi.org/10.1177/001872679004300802

Janssen, O. (2001). Fairness perceptions as a moderator in the curvilinear relationships between job demands, and job performance and job satisfaction. Academy of Management Journal, 44(5): 1039-50. Available: https://doi.org/10.5465/3069447

Jones, A., Norman, C. S. and Wier, B. (2010). Healthy lifestyle as a coping mechanism for role stress in public accounting. Behavioral Research in Accounting, 22(1): 21-41. Available: https://doi.org/10.2308/bria.2010.22.1.21

Judge, T. A., Heller, D. and Mount, M. K. (2002a). Five-factor model of personality and job satisfaction: a metaanalysis. Journal of Applied Psychology, 87(3): 530-41. Available: http://dx.doi.org/10.1037/0021$\underline{9010.87 .3 .530}$

Judge, T. A., Higgins, C. A., Thoresen, C. J. and Barrick, M. R. (1999). The big five personality traits, general mental ability, and career success across the life span. Personnel Psychology, 52(3): 621-52. Available: https://doi.org/10.1111/j.1744-6570.1999.tb00174.x

Judge, T. A., Bono, J. E., Ilies, R. and Gerhardt, M. W. (2002b). Personality and leadership: a qualitative and quantitative review. Journal of Applied Psychology, 87(4): 765-80. Available: http://dx.doi.org/10.1037/0021-9010.87.4.765

Karasek, R. and Theorell, T. (1992). Healthy work. Stress, productivity, and the reconstruction of work life. Basic Books: New York.

Kaur, J. (2017). Exploring relationships among ethical climate types and organizational commitment: A case of Indian banking sector. Journal of Indian Business Research, 9(1): 20-40. Available: https://doi.org/10.1108/JIBR-02-2015-0022

King'ori, J. (2016). Burnout and auditor work behaviours in Tanzanian public accounting firms. Business Management Review, $11(1)$ : 65-97. Available: http://www.journals.udsm.ac.tz/index.php/bmr/article/view/60

Kobasa, S. C. (1979). Stressful life events, personality, and health: an inquiry into hardiness. Journal of Personality and Social Psychology, 37(1): 1-11. Available: http://dx.doi.org/10.1037/0022-3514.37.1.1

Kock, N. (2015). Common method bias in PLS-SEM: A full collinearity assessment approach. International Journal of e-Collaboration (IJeC), 11(4): 1-10. Available: https://doi.org/10.4018/ijec.2015100101

Kumar, K. and Bakhshi, A. (2010). The five-factor model of personality and organizational commitment: Is there any relationship? Humanity And Social Sciences Journal, 5(1): 25-34.

Kwon, I. W. G. and Banks, D. W. (2004). Factors related to the organizational and professional commitment of internal auditors. Managerial Auditing Journal, 19(5): 606-22 Available: https://doi.org/10.1108/02686900410537748

Labatmedienè, L., Endriulaitienè, A. and Gustainienè, L. (2007). Individual correlates of organizational commitment and intention to leave the organization. Baltic Journal of Management, 2(2): 196-212. Available: https://doi.org/10.1108/17465260710750991

Larson, L. (2011). Gender differences in internal auditor job burnout. Internal Auditing, 26(1): 11-18.

Latan, H. and Ghozali, I. (2015). Partial least squares: Concepts, techniques and application using program SmartPLS 3.0. Diponegoro University Press: Semarang.

Latan, H., Jabbour, C. J. C. and de Sousa, J. A. B. L. (2017). Ethical awareness, ethical judgment, and whistleblowing: A moderated mediation analysis. In partial least squares path modeling. Springer: Cham. 311-37. 
Latan, H., Jabbour, C. J. C., de Sousa, J. A. B. L., Wamba, S. F. and Shahbaz, M. (2018). Effects of environmental strategy, environmental uncertainty and top management's commitment on corporate environmental performance: The role of environmental management accounting. Journal of Cleaner Production, 180: 297306. Available: https://doi.org/10.1016/j.jclepro.2018.01.106

Lee, R. T. and Ashforth, B. E. (1996). A meta-analytic examination of the correlates of the three dimensions of job burnout. Journal of Applied Psychology, 81(2): 123-33. Available: http://dx.doi.org/10.1037/00219010.81.2.123

Leiter, M. P. (2009). Commitment as a function of stress reactions among nurses: A model of psychological evaluations of work settings. Canadian Journal of Community Mental Health, 7(1): 117-33. Available: https://doi.org/10.7870/cjcmh-1988-0009

Leiter, M. P. and Maslach, C. (1988). The impact of interpersonal environment on burnout and organizational commitment. Journal of Organizational Behavior, 9(4): 297-308. Available: https://doi.org/10.1002/job.4030090402

Lewin, K. (1951). Field theory in social science. Harper: New York.

Li, Y. (2014). Building affective commitment to organization among Chinese university teachers: the roles of organizational justice and job burnout. Educational Assessment, Evaluation and Accountability, 26(2): 13552. Available: https://doi.org/10.1007/s11092-014-9192-3

Llorens, S., Bakker, A. B., Schaufeli, W. and Salanova, M. (2006). Testing the robustness of the job demandsresources model. International Journal of Stress Management, 13(3): 378-91. Available: http://dx.doi.org/10.1037/1072-5245.13.3.378

Low, G. S., Cravens, D. W., Grant, K. and Moncrief, W. C. (2001). Antecedents and consequences of salesperson burnout. European Journal of Marketing, 35(5/6): 587-611. Available: https://doi.org/10.1108/03090560110388123

Magnusson, D. and Endler, N. S. (1977). Interactional psychology: Present status and future prospects. In $d$. Magnusson \& n. S. Endler (eds.), personality at the crossroads: Current issues in interactional psychology. Erlbaum: New York. 3-31.

Malach-Pines, A. (2005). The burnout measure, short version. International Journal of Stress Management, 12(1): 78-88. Available: http://dx.doi.org/10.1037/1072-5245.12.1.78

Mark, G. M. and Smith, A. P. (2008). Stress models: A review and suggested new direction. Occupational Health Psychology, 3: 111-44. Available: http://psych.cf.ac.uk/home2/smith/Mark_and_Smith_Typeset.pdf

Martinow, K., Moroney, R. and Harding, N. (2016). Regulating audit quality via inspections and checklists: Impact on auditor commitment and turnover intentions. Working Paper, Monash University.

Maslach, C. (1982). Burnout: The cost of caring. Prentice Hall: New York.

Maslach, C. and Leiter, M. P. (1997). The truth about burnout. Jossey-Bass: San Francisco.

Maslach, C., Schaufeli, W. B. and Leiter, M. P. (2001). Job burnout. Annual Review of Psychology, 52(1): $397-422$. Available: https://doi.org/10.1146/annurev.psych.52.1.397

Mathieu, J. E. and Zajac, D. M. (1990). A review and meta-analysis of the antecedents, correlates, and consequences of organizational commitment. Psychological Bulletin, 108(2): 171-94. Available: http://dx.doi.org/10.1037/0033-2909.108.2.171

McManus, L. and Subramaniam, N. (2014). Organisational and professional commitment of early career accountants: do mentoring and organisational ethical climate matter? Accounting \& Finance, 54(4): 123161. Available: https://doi.org/10.1111/acfi.12029

Meyer, J. P. and Herscovitch, L. (2001). Commitment in the workplace: Toward a general model. Human Resource Management Review, 11(3): 299-326. Available: https://doi.org/10.1016/S1053-4822(00)00053-X

Meyer, J. P., Stanley, D. J., Herscovitch, L. and Topolnytsky, L. (2002). Affective, continuance, and normative commitment to the organization: A meta-analysis of antecedents, correlates, and consequences. Journal of Vocational Behavior, (1): 20-52. Available: https://doi.org/10.1006/jvbe.2001.1842

Mischel, W. and Shoda, Y. (1995). A cognitive-affective system theory of personality: reconceptualizing situations, dispositions, dynamics, and invariance in personality structure. Psychological Review, 102(2): 246-68. Available: http://dx.doi.org/10.1037/0033-295X.102.2.246

Mischel, W. and Shoda, Y. (1998). Reconciling processing dynamics and personality dispositions. Annual Review of Psychology, 49(1): 229-58. Available: https://doi.org/10.1146/annurev.psych.49.1.229

Mischel, W. and Ayduk, O. (2002). Self-regulation in a cognitive--affective personality system: Attentional control in the service of the self. Self and Identity, 1(2): 113-20. Available: https://doi.org/10.1080/152988602317319285

Morrow, P. C. (2011). Managing organizational commitment: Insights from longitudinal research. Journal of Vocational Behavior, 79(1): 18-35. Available: https://doi.org/10.1016/j.jvb.2010.12.008

Mowday, R. T., Steers, R. M. and Porter, L. W. (1979). The measurement of organizational commitment. Journal of Vocational Behavior, 14(2): 224-47. Available: https://doi.org/10.1016/0001-8791(79)90072-1

Muldoon, J., Keough, S. M. and Liguori, E. W. (2017). The role of job dedication in organizational citizenship behavior performance. Management Research Review, 40(10): 1042-57. Available: https://doi.org/10.1108/MRR-07-2016-0168

Norris, D. R. and Niebuhr, R. E. (1984). Professionalism, organizational commitment and job satisfaction in an accounting organization. Accounting, Organizations and Society, 9(1): 49-59. Available: https://doi.org/10.1016/0361-3682(84)90029-1 
Nunnally, J. and Bernstein, I. (1994). New psychometric theory. McGraw-Hill: New York.

Obeid, M., Salleh, Z. and Mohd Nor, M. (2017). The Mediating Effect of Job Satisfaction on The Relationship Between Personality Traits and Premature Sign-off. Academy of Accounting and Financial Studies Journal, 21(2): 1-17.

Omar, N. and Ahmad, Z. (2014). The relationship among ethical climate, job satisfaction, organizational commitment, and external auditor's turnover intention. Journal of Modern Accounting and Auditing, 10(2): 164-81. Available: https://doi.org/10.17265/1548-6583/2014.02.004

Ozer, D. J. and Benet-Martinez, V. (2006). Personality and the prediction of consequential outcomes. Annual Review of Psychology, 57: 401-21. Available: https://doi.org/10.1146/annurev.psych.57.102904.190127

Panaccio, A. and Vandenberghe, C. (2012). Five-factor model of personality and organizational commitment: The mediating role of positive and negative affective states. Journal of vocational behavior, 80(3): 647-58. Available: https://doi.org/10.1016/j.jvb.2012.03.002

Pervin, L. A. (1989). Persons, situations, interactions: The history of a controversy and a discussion of theoretical models. Academy of management Review, 14(3): 350-60. Available: https://doi.org/10.5465/amr.1989.4279066

Podsakoff, P. M., MacKenzie, S. B. and Podsakoff, N. P. (2012). Sources of method bias in social science research and recommendations on how to control it. Annual Review of Psychology, 63: 539-69. Available: https://doi.org/10.1146/annurev-psych-120710-100452

Podsakoff, P. M., MacKenzie, S. B., Lee, J.-Y. and Podsakoff, N. P. (2003). Common method biases in behavioral research: A critical review of the literature and recommended remedies. Journal of Applied Psychology, 88(5): 879-903. Available: https://doi.org/10.1037/0021-9010.88.5.879

Pooja, A. A., De Clercq, D. and Belausteguigoitia, I. (2016). Job stressors and organizational citizenship behavior: The roles of organizational commitment and social interaction. Human Resource Development Quarterly, 27(3): 373-405. Available: https://doi.org/10.1002/hrdq.21258

Raja, U., Johns, G. and Ntalianis, F. (2004). The impact of personality on psychological contracts. Academy of Management Journal, 47(3): 350-67. Available: https://doi.org/10.5465/20159586

Randall, D. M. (1987). Commitment and the organization: The organization man revisited. Academy of Management Review, 12(3): 460-71. Available: https://doi.org/10.5465/amr.1987.4306561

Rasoolimanesh, S. M., Jaafar, M., Kock, N. and Ramayah, T. (2015). A revised framework of social exchange theory to investigate the factors influencing residents' perceptions. Tourism Management Perspectives, 16: 335-45. Available: https://doi.org/10.1016/j.tmp.2015.10.001

Richter, N. F., Sinkovics, R. R., Ringle, C. M. and Schlaegel, C. (2016). A critical look at the use of SEM in international business research. International Marketing Review, 33(3): 376-404. Available: https://doi.org/10.1108/IMR-04-2014-0148

Riedo, V., Kraiczy, N. D. and Hack, A. (2017). Applying person-environment fit theory to identify personality differences between prospective social and commercial entrepreneurs: An explorative study. Journal of Small Business Management: Available: https://doi.org/10.1111/jsbm.12377

Ringle, C. M., Sarstedt, M., Mitchell, R. and Gudergan, S. P. (2018). Partial least squares structural equation modeling in HRM research. The International Journal of Human Resource Management: Available: https://doi.org/10.1080/09585192.2017.1416655

Rotter, J. B. (1966). Generalized expectancies for internal versus external control of reinforcement. Psychological Monographs: General and Applied, 80(1): 1-28. Available: http://dx.doi.org/10.1037/h0092976

Saks, A. M. (2006). Antecedents and consequences of employee engagement. Journal of Managerial Psychology, 21(7): 600-19. Available: https://doi.org/10.1108/02683940610690169

Salehi, M. and Gholtash, A. (2011). The relationship between job satisfaction, job burnout and organizational commitment with the organizational citizenship behavior among members of faculty in the Islamic Azad University-first district branches, in order to provide the appropriate model. Procedia-Social and Behavioral Sciences, 15: 306-10. Available: https://doi.org/10.1016/j.sbspro.2011.03.091

Salgado, J. F. (1997). The Five Factor Model of personality and job performance in the European Community. Journal of Applied Psychology, 82(1): 30-43. Available: http://dx.doi.org/10.1037/0021-9010.82.1.30

Sanders III, J. E., Hopkins, W. E. and Geroy, G. D. (2005). A causal assessment of the spirituality-leadershipcommitment relationship. Journal of Management, Spirituality \& Religion, 2(1): 39-66. Available: https://doi.org/10.1080/14766080509518566

Savery, L. K. and Syme, P. D. (1996). Organizational commitment and hospital pharmacists. Journal of Management Development, 15(1): 14-22. Available: https://doi.org/10.1108/02621719610107773

Schaufeli, W. B. and Enzmann, D. (1998). The burnout companion to study and research: A critical analysis. Taylor and Francis: London, UK.

Shirom, A. (2003). Job-related burnout: A review. In J. C. Quick \& L. E. Tetrick (Eds.), Handbook of occupational health psychology American Psychological Association: Washington, DC. 245-64.

Shore, L. M., Barksdale, K. and Shore, T. H. (1995). Managerial perceptions of employee commitment to the organization. Academy of Management Journal, 38(6): 1593-615. Available: https://doi.org/10.5465/256845

Silbiger, A., Berger, R., Barnes, B. R. and WS Renwick, D. (2017). Improving expatriation success: the roles of regulatory focus and burnout. British Journal of Management, 28(2): 231-47. Available: https://doi.org/10.1111/1467-8551.12187 
Smith, K. J. and Emerson, D. J. (2017). An analysis of the relation between resilience and reduced audit quality within the role stress paradigm. Advances in Accounting, 37: 1-14. Available: https://doi.org/10.1016/j.adiac.2017.04.003

Sommer, S. M., Bae, S. H. and Luthans, F. (1996). Organizational commitment across cultures: The impact of antecedents on Korean employees. Human Relations, 49(7): 977-93. Available: https://doi.org/10.1177/001872679604900705

Steers, R. M. (1977). Antecedents and outcomes of organizational commitment. Administrative Science Quarterly, 22(1): 46-56. Available: https://doi.org/10.2307/2391745

Sweeney, J. T. and Summers, S. L. (2002). The effect of the busy season workload on public accountants' job burnout. Behavioral Research in Accounting, 14(1): 223-45. Available: https://doi.org/10.2308/bria.2002.14.1.223

Swider, B. W. and Zimmerman, R. D. (2010). Born to burnout: A meta-analytic path model of personality, job burnout, and work outcomes. Journal of Vocational Behavior, 76(3): 487-506. Available: https://doi.org/10.1016/j.jvb.2010.01.0

Voorhees, C. M., Brady, M. K., Calantone, R. and Ramirez, E. (2016). Discriminant validity testing in marketing: an analysis, causes for concern, and proposed remedies. Journal of the Academy of Marketing Science, 44(1): 119-34. Available: https://doi.org/10.1007/s11747-015-0455-4

Watson, D., Clark, L. A. and Harkness, A. R. (1994). Structures of personality and their relevance to psychopathology. Journal of Abnormal Psychology, 103(1): 18-31. Available: http://dx.doi.org/10.1037/0021-843X.103.1.18

White, J. K., Hendrick, S. S. and Hendrick, C. (2004). Big five personality variables and relationship constructs. $\begin{array}{llll}\text { Personality and Individual Differences, } & 37(7): & 1519-30 . & \text { Available: }\end{array}$ https://doi.org/10.1016/j.paid.2004.02.019

Whitener, E. M. and Walz, P. M. (1993). Exchange theory determinants of affective and continuance commitment and turnover. Journal of Vocational Behavior, 42(3): 265-81. Available: https://doi.org/10.1006/jvbe.1993.1019

Zimmerman, R. D., Boswell, W. R., Shipp, A. J., Dunford, B. B. and Boudreau, J. W. (2012). Explaining the pathways between approach-avoidance personality traits and employees' job search behavior. Journal of Management, 38(5): 1450-75. Available: https://doi.org/10.1177/0149206310396376 